\title{
KNOWLEDGE, ATTITUDE AND PRACTICE OF INFECTION CONTROL AMONG THE DENTAL STUDENTS
}

\author{
Subashri, $\mathbf{A}^{1}$ and Chandana ${ }^{2}$ \\ 1II BDS Student Prosthodontics Department Saveetha Dental College Chennai - 600077 \\ ${ }^{2}$ Department of Conservative Dentistry Saveetha Dental College Chennai- 600077
}

DOI: http://dx.doi.org/10.24327/ijrsr.2017.0803.0068

\begin{tabular}{l}
\hline ARTICLE INFO \\
\hline Article History: \\
Received $15^{\text {th }}$ December, 2016 \\
Received in revised form $25^{\text {th }}$ \\
January, 2017 \\
Accepted $23^{\text {rd }}$ February, 2017 \\
Published online $28^{\text {th }}$ March, 2017 \\
\hline
\end{tabular}

\section{Article History:}

Received $15^{\text {th }}$ December, 2016

Received in revised form $25^{\text {th }}$

Accepted $23^{\text {rd }}$ February, 2017

Published online $28^{\text {th }}$ March, 2017

\begin{abstract}
Aim: To assess the attitude, knowledge and practice of infection control among the dental students Objective: A self administered questionnaire consisting of 17 questions will be administrated to 200 dental students. The questionnaire will also be made available online for more easy access. The data will be collected and imported to spss online software and the results will be obtained.

Background: Dentists are at high risk of exposure to cross-infection with blood-borne pathogens, such as hepatitis B virus and other viruses and bacteria that colonize the oral cavity and the upper respiratory tract. This risk is enhanced by accidental injuries caused by dental instruments during patient treatment.

Reason: Infections can be prevented using safety precautions and implementing infection control guidelines. Many dental patients may appear clinically healthy according to physical examination and medical history. Hence, risk management strategies or standard precautions should not be applied based on the patient's appearance. So knowledge and practice of the infection control is very important for any dental practitioner.
\end{abstract}

Copyright (C) Subashri, A and Chandana, 2017, this is an open-access article distributed under the terms of the Creative Commons Attribution License, which permits unrestricted use, distribution and reproduction in any medium, provided the original work is properly cited.

\section{INTRODUCTION}

Transmission of infectious agents between the patient and doctor within the clinical environment is defined as cross infection ${ }^{1}$. Certain basic routines must be adopted by the dental professionals to prevent cross infections. Dental health professionals are at high exposure to various micro organisms such as hepatitis B, hepatitis C, staphylococci, HIV, tuberculosis, mumps and influenza. These bacteria and viruses colonize the oral cavity and upper respiratory tract ${ }^{2}$. Transmission of infection can happen through several methods such as direct or indirect ${ }^{3}$. A susceptible host, pathogen and a route through which it may enter are needed for infection to spread. Effective infective control strategies should break one or more of these links in the chain to prevent infection from occurring. A study conducted in late 1970's found that dentists are three times more prone to hepatitis B than the general public ${ }^{4}$. An essential element for cross infection control is wearing of gloves by the dental health personnals 5 . Major source of infection is considered to be hands ${ }^{6}$. The infected blood may retain into the nails for up to 5 days $^{7}$. And it is also hard to remove the contaminated blood from hands. Dental colleges are responsible for providing knowledge about the cross infection and the control measures to be taken to protect the patients ${ }^{8}$. The updated guidelines on infection control techniques were given by Centre for Disease Control and Prevention of the United States of America in $2003^{9}$. Despite of such emphasis placed on the infection control procedures only a few dentists adhere to these techniques in their practice ${ }^{10}$. Several studies have shown that even dental students do not practice these procedures properly ${ }^{11,12}$.

\section{MATERIALS AND METHODS}

A questionnaire was circulated among various dental students of different dental colleges in Chennai. The study population of 200 students completed the questionnaire which consisted of 17 questions. The questionnaire was prepared in such a way that will obtain the knowledge, attitude and practice scores among the students. The study population comprised of third, fourth and final years. The questionnaire was given to the students in the classroom and asked to fill within 15 minutes. The interns were given the same questionnaire in various departments. The questionnaire consisted of questions which assessed the knowledge, questions to assess attitude and questions to judge the infection control practices among the respondents.

Chi- square test was used to compare the categorical variables. Analysis of variance (ANOVA) was used to compare the mean 
of knowledge, attitude and practice scores. A p value of less than 0.005 was considered to be significant. The results were performed using spss online software version 20.

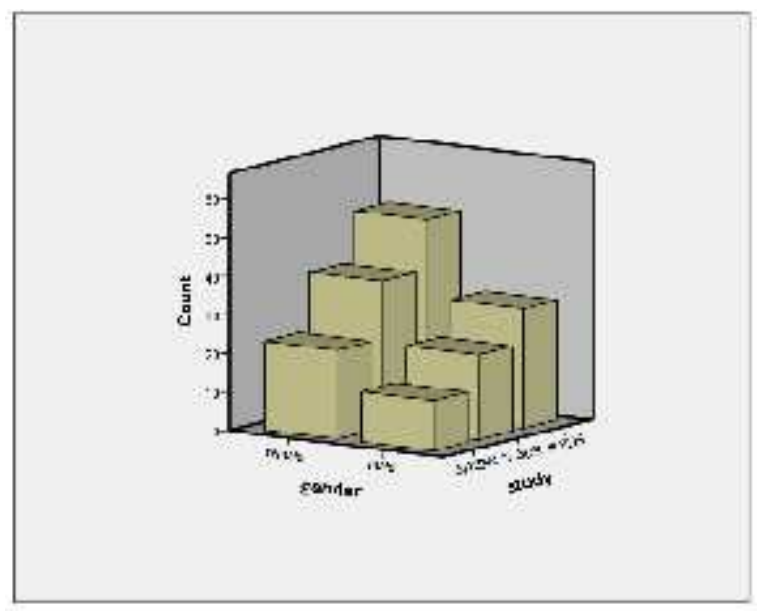

Fig 1 Gender \& study bar graph

Table 1 Gender * study Crosstabulation

\begin{tabular}{|c|c|c|c|c|}
\hline \multicolumn{5}{|c|}{ Count } \\
\hline & \multicolumn{3}{|c|}{ study } & \multirow{2}{*}{ Total } \\
\hline & III BDS & IV BDS & INTERN & \\
\hline \multirow{2}{*}{ gender female } & 51 & 38 & 23 & 112 \\
\hline & 31 & 22 & 13 & 66 \\
\hline Total & 82 & 60 & 36 & 178 \\
\hline
\end{tabular}

\section{RESULTS}

Out of 200 students, 178 voluntarily participated in the survey. Out of which 112 were females and 66 males. Not even $50 \%$ of the undergraduates used antiseptic solution to wash their hands before and after patient examination. All most all the students considered isolation to be an important infection control procedure. Many of them even that knowledge that ineffective sterilization can transmit infection from one patient to another. The questions were divided into knowledge, attitude and practice based and scores were calculated separately.

Table 2 Mean of knowledge, attitude and practice scores regarding infection control

\begin{tabular}{ccccc}
\hline S.NO & Year of study & $\begin{array}{c}\text { Knowledge } \\
\text { Mean(S.D) }\end{array}$ & $\begin{array}{c}\text { Attitude } \\
\text { Mean(S.D) }\end{array}$ & $\begin{array}{c}\text { Practice } \\
\text { Mean(S.D) }\end{array}$ \\
\hline 1. & III BDS & $2.7(0.8)$ & $3.0(0.7)$ & $3.8(0.8)$ \\
2. & IV BDS & $2.5(0.7)$ & $3.2(0.7)$ & $4.2(0.8)$ \\
3. & INTERNS & $2.7(0.7)$ & $3.0(0.6)$ & $4.0(0.7)$ \\
& TOTAL & $2.6(0.8)$ & $3.1(0.7)$ & $4.0(0.8)$ \\
\hline
\end{tabular}

Table 3 Study * knowledge Crosstabulation

\begin{tabular}{|c|c|c|c|c|c|c|c|}
\hline & \multicolumn{5}{|c|}{ knowledge } & \multirow{2}{*}{ Total } \\
\hline & & 1 & 2 & 3 & 4 & 5 & \\
\hline \multirow{4}{*}{ study } & III BDS & 4 & 29 & 37 & 10 & 2 & 82 \\
\hline & IV BDS & 5 & 24 & 27 & 4 & 0 & 60 \\
\hline & INTERN & 3 & 6 & 24 & 3 & 0 & 36 \\
\hline & Total & 12 & 59 & 88 & 17 & 2 & 178 \\
\hline
\end{tabular}

Table 4 study * attitude Crosstabulation

\begin{tabular}{ccccccc}
\hline & \multicolumn{4}{c}{ attitude } & \multirow{2}{*}{ Total } \\
\cline { 2 - 6 } & & $\mathbf{2}$ & $\mathbf{3}$ & $\mathbf{4}$ & $\mathbf{5}$ & \\
\hline \multirow{3}{*}{ study } & III BDS & 20 & 42 & 20 & 0 & 82 \\
& IV BDS & 9 & 27 & 22 & 2 & 60 \\
& INTERN & 8 & 20 & 8 & 0 & 36 \\
\multicolumn{2}{c|}{ Total } & 37 & 89 & 50 & 2 & 178 \\
\hline
\end{tabular}

There were 7 knowledge based, 5 attitude based and 5 practice based questions in the questionnaire framed. Each correct response added a score of 1 . Mean knowledge, attitude and practice scores were 2.6(0.8), 3.1(0.7), 4.0(0.8)

Table 5 study * practice Crosstabulation

\begin{tabular}{ccccccc}
\hline & & \multicolumn{4}{c}{ practice } & \multirow{2}{*}{ Total } \\
\cline { 3 - 6 } & & $\mathbf{2}$ & $\mathbf{3}$ & $\mathbf{4}$ & $\mathbf{5}$ & \\
\hline \multirow{3}{*}{ study } & III BDS & 3 & 26 & 33 & 20 & 82 \\
& IV BDS & 2 & 10 & 21 & 27 & 60 \\
& INTERN & 1 & 7 & 17 & 11 & 36 \\
\multicolumn{2}{c}{ Total } & 6 & 43 & 71 & 58 & 178 \\
\hline
\end{tabular}

Table 6 ANOVA test to check the significance of study

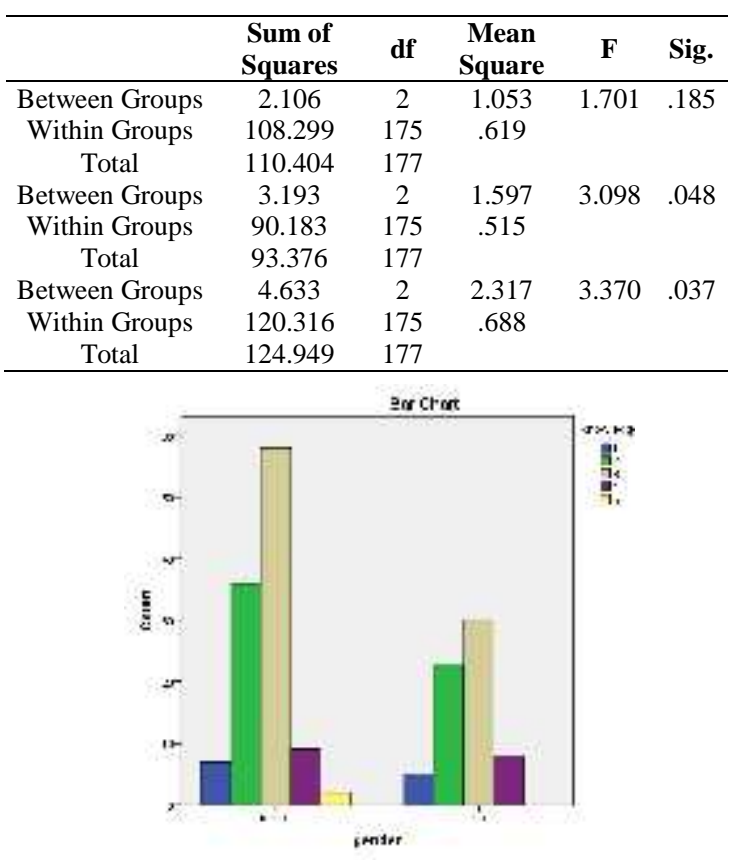

Fig 2 Gender vs knowledge

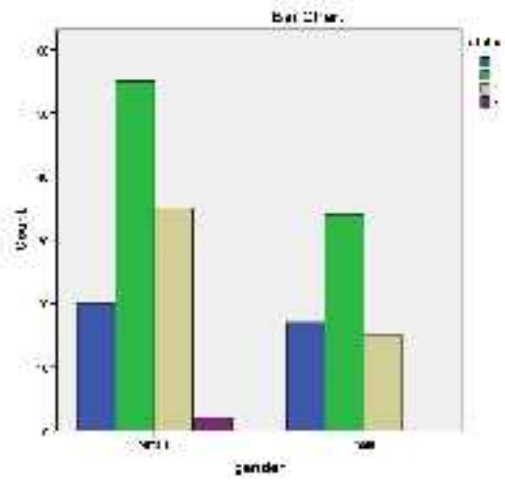

Fig 3 Gender vs attitude

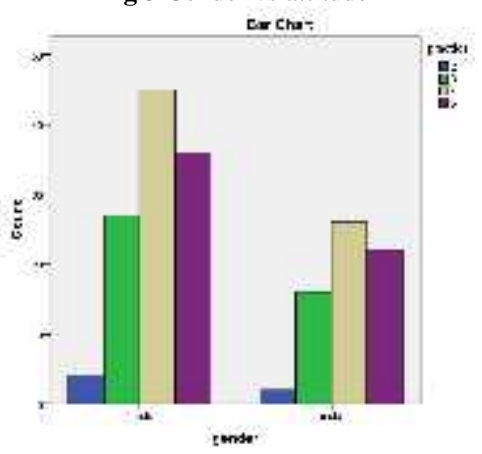

Fig 4 Gender vs practice 


\section{DISCUSSION}

Unfortunately, most of the dental students were not vaccinated by Hepatitis- B vaccine. The Dental Council of India is made mandatory for all dental students to be vaccinated with Hepatitis-B vaccine, but it is not mandatory in schools. Even though the students were taught to use antiseptic solutions before and after patient examination they didn't do so. Only hand full of students used face mask, gloves, eye wear and protective clothing. The preference to face mask and gloves was given more than the eye wear and protective clothing in most of the dental schools. It is very rare to see students using eye shields and protective clothing. The knowledge about the infection control measures was poor among the students. Reasons for this could be inadequate training techniques, inappropriate supply of equipment. Similar results were found in studies by Henrique et $a l^{13}$, Askarian and Assadian $^{14}$, Ogden et al $^{15}$, Taiwo and Aderinokun ${ }^{16}$ regarding students in Brazil, UK, Iran and Nigeria.

Most of the students used autoclave to sterilize instruments in this study. A ten year study was conducted by Henrique et al ${ }^{13}$ regarding the infection control rules. The use of autoclave increased as the years passed by. In $199583.8 \%$ of them used autoclave and in $2005,95.9 \%$ to sterilize the instruments. But no student can describe the correct pressure, temperature and time regarding the autoclave either in 1995 or in 2005. However in this study the students were more aware about the above details. The high percentage about the sterilization techniques resulted among good knowledge about the same. A study showed that $55 \%$ of the students preferred oral mouth rinse before and after commencement of any procedure ${ }^{17 .}$

Mean knowledge, attitude and practice scores were 2.6(0.8), $3.1(0.7)$, 4.0(0.8) respectively. Cross tabulation was done between study-knowledge, study-attitude and study-practice and the results are tabulated. Bar graphs are given regarding the gender and knowledge, attitude and practice separately. Anova test was done to check the significance of knowledge, attitude and practice scores. It was found that attitude and practice scores were significant while knowledge scores were not significant.

\section{CONCLUSION}

This study indicates that there is lack of knowledge about the basics of infection control and the prevention transmission of communicable disease among the dental students. Therefore continuous educational programs, training workshops on infection control isolation should be given to students to enhance their clinical practice.

\section{References}

1. Yüzbasioglu E, Saraç D, Canbaz S, Saraç YS, Cengiz S. A survey of cross-infection control procedures: Knowledge and attitudes of Turkish dentists. J Appl Oral Sci 2009; 17(6):565-9.
2. Milward MR, Cooper PR. Competency assessment for infection control in the undergraduate dental curriculum. Eur J Dent Educ 2007; 11(3):148-54.

3. Verrusio AC, Neidle EA, Nash KD, Silverman S, Horowitz AM, Wagner KS. The dentist and infectious diseases: a national survey of attitudes and behavior. J Am Dent Assoc 1989; 118:553-62.

4. Mosley JW, Edwards VM, Casey G, Redecker AG, White E. Hepatitis B virus infection in dentists. $N$ Engl J Med 1975; 293:729-34.

5. Rustage KJ, Rothwell PS, Brook IM. Evaluation of a dedicated dental procedure glove for clinical dentistry. Br Dent J 1987; 103:193-5.

6. Burke FJT, Wilson NHF, Bogge HFJ. Glove wearing by dental surgery assistants. Dent Update 1993; 20:385-7.

7. Allen AL, Organ RJ. Occult blood accumulation under the nger nails: a mechanism for the spread of bloodborne infection. J Am Dent Assoc 1982; 105:455-9.

8. de Souza RA, Namen FM, Galan J Jr, Vieira C, Sedano HO. Infection control measures among senior dental students in Rio de Janeiro State, Brazil. J Public Health Dent 2006; 66(4):282-4.

9. Kohn WG, Collins AS, Cleveland JL, Harte JA, Eklund $\mathrm{KJ}$, Malvitz DM, et al. Guidelines for infection control in dental health-care settings-2003. MMWR Recomm Rep 2003; 52(RR-17):1-61.

10. Jain M, Sawla L, Mathur A, Nihlani T, Ayair U, Prabu $\mathrm{D}$, et al. Knowledge, attitude and practice towards droplet and airborne isolation precautions amongs dental health care professionals in India. Med Oral Patol Oral Cir Bucal 2010; 15(6):e957-61.

11. Sofola OO, Folayan MO, Denloye OO, Okeigbemen SA. Occupational exposure to bloodborne pathogens and management of exposure incidents in Nigerian dental schools. J Dent Educ 2007; 71(6):832-7.

12. Singh A, Purohit BM, Bhambal A, Saxena S, Singh A, Gupta A. Knowledge, attitudes, and practice regarding infection control measures among dental students in Central India. J Dent Educ 2011; 75(3):421-7.

13. Henrique M, Claudia T, Braz F, Lúcia A, Martins S, Almeida I. Attitudes and behavior of dental students concerning infection control rules: a study with a 10-year interval. Braz, Dent J 2009; 20(3).

14. Askarian M, Assadian O. Infection control practices among dental professionals in Shiraz Dentistry School, Iran. Arch Iranian Med 2009; 12(1):48-51.

15. Ogden GR, Bahrami M, Sivarajasingam V, Phillips G. Dental students' knowledge and compliance in crossinfection control procedures at a UK dental hospital. Oral Dis 1997; 3(1):25-30.

16. Taiwo JO, Aderinokun GA. Assessing cross infection prevention measures at the dental clinic, University College Hospital, Ibadan. Afr J Med Sci 2002; 31(3):213-7.

17. Leggat PA, Kedjarune U. Bacterial aerosols in the dental clinic: a review. Int Dent J 2001; 51:39-44.

\section{How to cite this article:}

Subashri, A and Chandana.2017, Knowledge, Attitude and Practice of Infection Control among the Dental Students. Int J Recent Sci Res. 8(3), pp. 16072-16074. DOI: http://dx.doi.org/10.24327/ijrsr.2017.0803.0068 